\title{
Impact of Toxic Leadership on Counterproductive Work Behavior with the Mediating role of Psychological Contract Breach and Moderating role of Proactive Personality
}

\author{
MUHAMMAD BILAL KAYANI ${ }^{1}$, IMRAN IBRAHIM ALASAN ${ }^{2}$ \\ ${ }^{1}$ LIMKOKWING UNIVERSITY OF CREATIVE TECHNOLOGY, CYBERJAYA, MALAYSIA \\ E-mail: mbkiani@gmail.com \\ ${ }^{2}$ LIMKOKWING UNIVERSITY OF CREATIVE TECHNOLOGY, CYBERJAYA, MALAYSIA \\ E-mail: imran.ibrahim@limkokwing.edu.my
}

\begin{abstract}
This paper focused the conceptualizations of toxic leadership and analyzes the relationship between toxic leadership and counterproductive work behavior (CWB). The mediating role of psychological contract breach was measured between the toxic leadership and counterproductive work behavior, also by analyzing the moderating effect of proactive personality. The selected sample for research comprised of 355 nurses serving in public sector of Pakistan and questionnaire was used as a research tool. Findings of the data revealed that toxic leadership is having a positive significant relationship with CWB and a negative with PCB in partial mediation model. PCB was found to be positively associated with CWB whereas Proactive personality was identified for weakening the relationship of PCB and CWB. The results of the study elaborated that firms ought to illuminate unmistakably to managers about the antagonistic outcomes brought about by toxic oversight, and may join rules or approaches to rebuff toxic practices. Given the counterproductive impact of toxic leadership, more information is exclusively required regarding causes of toxic leadership and the paper concluded with recommendations for future research and action.
\end{abstract}

Keywords: Toxic Leadership, Psychological Contract Breach, Counterproductive Work Behavior, Proactive Personality

JEL classification: J53, M10, M59. 


\section{Introduction}

The phenomenon of leadership is discussed to improve the productivity and working performance of employees. In pas various researches have discussed the bright side of leadership highlighting the positive ways to enhance leader-follower relationship whereas few researches are conducted for the darker aspects of leadership. The area of leadership achieves its significance by analyzing its impact on organizational success. Bad and dark leaders in such a case have adverse impacts on organizational output.

The leadership qualities and the relations between leader character and leadership styles has a lot of variations depending on the situation and social hereditary (Judge et al., 2009). But the exploration of the phenomenon has featured the negative or clouded side of leadership (Griffin and Lopez, 2005, Wu and Hu, 2009, Naseer et al., 2016) by revealing destructive parts of leadership that can have negative impacts (Schyns and Hansbrough, 2010) on such factors as non-appearance, turnover, viability (Tepper et al., 2006), enthusiastic depletion (Harvey et al., 2007), degenerate work conduct (Zellars et al., 2002), work fulfilment (Tepper, 2000, Tepper et al., 2004), stress (Tepper, 2000), and execution (Aryee et al., 2007). These destructive leadership behaviors have been conceptualized and reviewed with a title of toxic leadership (Burns Jr, 2017), abusive supervision (Tepper, 2000), destructive leadership (Schyns and Hansbrough, 2010), and exploitative leadership (Schmid et al., 2019).

Pelletier (2010) described destructive leadership as the precise and repeated conduct by a leader, administrator, or supervisor that manipulates the genuine enthusiasm of the organization by disrupting the organization's objectives. Aasland et al. (2010) included that destructive leadership has various dimensions that includes working against organizational goals, mishandling of subordinates or other unlawful conduct etc. Steele (2011) mentioned that destructive leaders practice predominance, pressure, and control, whereas the constructive leaders use impact, influence, and responsibility. Reed and Bullis (2009) also added that destructive leadership, toxic leadership, and pretty tyranny are applied reciprocally. This is the reason, given idea in paper is aiming to subordinate toxic leadership under the general class of destructive leadership. As indicated by Gallus et al. (2013), destructive leadership style has profound roots both mentally and organizationally.

These negative behaviors of furious and destructive leaders can have adverse impact on the psychological contract of employees resulting into negative effects. Employees working under destructive bosses get distressed due to mental and physical fatigue resulting in psychological breach of contract. Researches previously have shown a positive and significant correlation between psychological contract breach and negative effects in the form of counterproductive work behavior (Li and Chen, 2018), whereas destructive leaders in previously researches found adversely effecting both on the subordinates and the organizations.

\section{Literature Review}

\subsection{Toxic Leadership}

Toxic leadership usually associated with behaviors comprising of threat and intimidation that may leave the subordinates into a worse situation. Singh et al. (2018) in his study explored that toxic leaders are always finding ways to shatter and bring down the confidence and interest of their subordinates. Toxic leaders are not regular and planned tyrant managers but unreliable and troublesome mates who implements dangerous practices that spoils individuals professional growth and future of the organization (Schmidt, 2008). Although the behavior of toxic leaders varies but they deliberately hurt others or improve themselves to others detriment. In order to confuse the matter, these leaders might appear as legends or the other way around. These toxic leaders do not use harsh behavior for turning down their subordinates rather they exhibit toxicity through softness (Reed, 2004). Reed (2004) stated that toxic leaders are short sighted as they can not visualize huge future damage of organization through their acts. 
Consequently, the drive behind this exploration is to inspect the degree to which toxic leadership rises above the work limit to influence subordinates' psychological contract and the response as counterproductive work behavior if the contract breaches. Therefore, this research examines how toxic leadership makes emotional weariness, which impacts workers' psychological contract and counterproductive work behavior. The moderating part of a proactive character on the connection between toxic leadership and the result factors has been examined. In this case Luthans et al.(1998) mentioned that under the toxic supervision subordinates with high powers are removed just to make a group of people who could obey leaders without arguing. We along these lines consider Pakistanis to be as ideal for this examination (Naseer et al., 2016).

\subsection{Psychological Contract Breach}

The idea of developing and keeping up strong associations with employees is vital to organizational achievement. The 'psychological contract' (PC) has been a significant instrument in this undertaking for right around 30 years (O'Donohue et al., 2018). PCs suggest to employees' convictions with respect to the terms and states of their trade concurrence with their manager (Rousseau, 1995, Rousseau, 1989).

A few hypothetical structures have been utilized to disclose a worker's reaction to psychological contract breach. As per control hypothesis (Carver and Scheier, 1982), when workers see an inconsistency between what they were guaranteed by the organization and what they got, they attempt to kill or diminish the unevenness. This hypothetical method of reasoning would recommend a particular association between the breach and the kind of the behavioral response.

Another significant point contended by Morrison and Robinson (1997) is of the view that contract breach won't really lead to the extreme passionate response regularly likened with the term psychological breach of contract (Rousseau, 1989). They recommended that whether the psychological view of a break prompts a passionate response, and the power of that response, relies upon a translation cycle whereby the representative connects significance to the apparent penetrate (Oatley and Jenkins, 1992). In this study the psychological contract breach would be studied as mediator in response to toxic behaviors of leaders.

\subsection{Counterproductive Work Behavior}

One of the focal topics inside the field of Industrial/Organizational Psychology is planning the connection between individual qualities (e.g., skills, capacities, character traits) and work environment conduct. Understanding these connections grants organizations to choose people with qualities connected to work environment practices. Generally, staff determination research has zeroed in essentially on recognizing competitors prone to take part in alluring work conduct (e.g., those liable to deliver work of high caliber, or to create work at a high rate (Campbell et al., 1990).

The definition of counterproductive work behavior includes behavior that is focused at both people and at the organization, as the two sorts of activities can have extreme outcomes on the organization. The concept of counterproductive work behaviors is very wide. In this paper counterproductive work behavior would be studied in particular to the outcome of toxic leadership.

\subsection{Proactive Personality}

The role of proactive personality in context to leadership has previously discussed by many researchers (Newman et al., 2017, Nguyen et al., 2016, Caniëls et al., 2018). In context of bad leadership, the available literature is silent for proactive personalities. This paper fills up the gap by identifying role of proactive personality in reducing counterproductive work behavior effect by toxic leaders. Newman et al. (2017) in his research discussed proactive personality in regards to Leader Member Exchange theory. Due to progressively decentralized organizational structures and continually changing work requests, organizations want employees who are willing and ready to adequately venture out of their customary work jobs. Such profoundly proactive people, who perceive 
their capacity to impact just as to adapt to the evolving conditions, help their organizations create and keep up upper hand (Crant, 2000). Henceforth, they are resources for their organizations (Crant, 2000, Frese et al., 1996, Parker, 2000).

Working environment proactivity is reflected by a few unique practices, for example, effectively acclimating to a new position (Ashford and Black, 1996), tackling issues and actualizing arrangements effectively (Parker et al., 2006), stirring things up (Van Dyne and LePine, 1998), assuming responsibility to achieve change (Morrison and Phelps, 1999), applying additional endeavors (Rank et al., 2007), and performing past pre-determined desires (Parker et al., 1997).

Despite the fact that there are a few proactivity related develops inside hierarchical examination, the one that best catches the dispositional highlights of proactivity is known as proactive personality (Bateman and Crant, 1993). Starting more than twenty years prior in the hierarchical conduct and the executives writing, proactive personality is one of the soonest proactivity-related builds. As conceptualized by Bateman (2017), proactive personality is an inclination to effectively control situational powers and to impel change in the climate.

\subsection{Impact of Toxic Leadership on Counterproductive Work Behavior}

Previous studies have counterproductive work behavior as a negative emotion of followers or employees that is intended to harm or damage the organization. This research paper by using semimediation model explains the impact of toxic leaders upon counterproductive work behavior. Singh et al. (2018) in his article investigated and found that toxic leaders are aimed at threat and intimidation and for them counterproductive work behavior holds a more expected outcome. It can incorporate obvious acts, for example, animosity and robbery or more inactive acts, for example, deliberately neglecting to adhere to guidelines or accomplishing work erroneously. Counterproductive work behavior has been conceptualized in various manners, including authoritative hostility (Neuman and Baron, 1998, Fox and Spector, 1999), reserved conduct (Giacalone and Greenberg, 1997), wrongdoing (Hogan and Hogan, 1989), abnormality (Hollinger, 1986, Robinson and Bennett, 1995), reprisal (Skarlicki and Folger, 1997), vengeance (Bies et al., 1997), and mobbing/harassing (Zapf et al., 1996). The regular topic is that these practices are destructive to the association by legitimately influencing its working or property, or by harming representatives that will diminish their viability. Various specialists (Fox and Spector, 1999, Robinson and Bennett, 1995) have discovered proof that impression of counterproductive work behavior's as well as relations of counterproductive work behaviors to individual and authoritative factors permit us to recognize two classes of practices: those focusing on the association and those focusing on different people in the association.

The term toxic leadership is often seen under the shadow of destructive leadership (Einarsen et al., 2007) or dark leadership (Paulhus and Williams, 2002). The toxic leadership is not explicitly defined by the theorists but is often referred to as harmful or bad specially in regards to followers by few of the researchers (Padilla et al., 2007, Lipman-Blumen, 2010). Such leaders are accused of influencing followers in way that increases stress levels by reducing motivation and performance (Kurtulmuş, 2020). They may have additionally insensitivity which makes them inert to the others which in the long run harm the subordinates (Paulhus, 2014). Such leaders additionally display terrorizing and tormenting practices, and they likewise will in general participate in dishonest and unethical choices at whatever point it esteems to be needed (Webster et al., 2016). toxic leadership behaviors may also cause hierarchical or individual bad results leading to environmental deviances(Mitchell and Ambrose, 2007), retaliatory activity from subordinates (Tripp et al., 2002), estrangement (Rosenthal and Pittinsky, 2006), lower work fulfillment (Tepper, 2000), and organic and mental pressure (Leymann and Gustafsson, 1996). Toxic leaders additionally assault the confidence of their devotees, and representatives report that they are scorned publicly (Dobbs and Do, 2019). These factors thus increasing negativity among followers raises stress among them leading to retaliation in form of counterproductive work behavior.

$\mathbf{H}_{1:}$ Toxic Leadership have a significant positive impact on counterproductive work behavior. 


\subsection{Psychological Contract Breach and Counterproductive Work Behavior}

Counterproductive work conduct is a critical reason for failure and can make tremendous monetary misfortunes ventures (Tian et al., 2014). For instance, in the United States, 33-75\% of workers take part in various types of counterproductive work behavior (Harper, 1990), causing loss of 1 trillion dollars every year. These practices encompasses burglary (120 billion dollars), work environment brutality (4.2 billion dollars), and fake exercises (in excess of 900 billion dollars; Banks et al., 2012).Ceschi et al. (2016) found that the connection between work requests and counterproductive work behavior can be directed by character's characteristics (i.e., coarseness and genuineness lowliness). From a social trade viewpoint, Colbert et al. (2004) found that the impression of a steady workplace was contrarily identified with counterproductive work behavior. As a system for understanding the business relationship, the idea of the psychological contract has increased more consideration (Conway and Briner, 2009, Cassar and Briner, 2011). The psychological contract has been characterized by the corresponding trade, connection between an employee and organization, and common desires held by them (Kotter, 1973, Rousseau and Tijoriwala, 1998). Given that the business holds more force (e.g., dynamic) than regular workers, the person can set guidelines to compel employees to satisfy their commitments or guarantees; subsequently, the business scarcely sees psychological contract breach. Subsequently, we just focus on the impacts of psychological contract breach observed by employees. With hierarchical changes, for example, delayering, cutting back and repetition, workers may more effectively see psychological contract breach as a recent memory (Sturges et al., 2005).

Rousseau (1989) mentioned the impact of psychological contract breach on employee's performance and commitment level. Earlier investigations have proposed that psychological contract breach affects business related perspectives (Bal et al., 2008) and practices (Cantisano et al., 2008, Quratulain et al., 2018) for example, decreased occupation fulfillment (Wang and Hsieh, 2014), citizenship conduct (Hejazi, 2016), authoritative responsibility (Schmidt, 2016), and enlarged turnover goals (Raja et al., 2004). In addition, past examinations have essentially explored the part of inspirational mentalities (e.g., trust, work fulfillment, association duty, and so forth) that have assumed a function in the connection among psychological contract breach and business-related practices. Few examinations have proposed that psychological contract breach is decidedly identified with counterproductive work behavior. All the more explicitly, psychological contract breach can trigger optional truancy (Deery et al., 2006), against citizenship conduct (Kickul and Lester, 2001) and a reduction in-job work execution (Turnley and Feldman, 2000).

Although the connection between psychological contract breach and counterproductive work behavior has not been analyzed thoroughly (Zhao et al., 2007, Jensen et al., 2010). Normally, It is studied with a restricted scope of counterproductive work behaviors with an absence of thought of the function of negative mentalities on commitment in counterproductive work behavior. To fill this hole, in the current investigation we endeavored to uncover the systems for the connection among psychological contract breach and counterproductive work behavior.

$\mathrm{H}_{2}$ : Psychological Contract Breach has a positive significant impact on Counterproductive Work Behavior.

\subsection{Mediating Role of Psychological Contract Breach}

The relationship among leaders and their subordinates can be clarified through psychological contract theory (Rousseau, 2011). According to this hypothesis, there exists a give and take relationship among leaders and subordinates and the breach of this agreement can bring about negative results having suggestions for workers' prosperity (Ali, 2014). In light of this hypothesis it may be expected that egotistical demeanor toxic leaders breach this agreement which influences the employees negativity (Naeem and Khurram, 2020). Naeem and Khurram (2020) also found in their research that subordinates psychological wellbeing is negatively and significantly associated with toxic leadership. Their results showed that employees encountering toxic bosses have an increased stressed 
level giving rise to negativity among them. Penney and Spector (2005) stated that negative effectivity and counterproductive work behavior are positively associated.

Lipmen-Blumen (2005) investigated certain characteristics of such toxic leaders that harm both the subordinates and the organization. Lipmen-Blumen (2005) found toxic leaders to be poisonous, adopt a deleterious practices and policies that includes unreachable targets, developing excessive competition and create a blame-game culture. As per Fraher (2016), toxic leaders set destructive targets and utilize destructive techniques of command. These traits of toxic leaders lead to greater negativity among followers with increased stressed as they have to work extra working hours to reach such goals and bear too much politics to sustain in excessive competition. For which subordinates react or retaliate in form of counterproductive work behavior.

The hypothesis may also get its support from social exchange theory. Since a psychological contract is established in social exchange theory (Rousseau, 1995), which is viewed as one of the most compelling applied ideal models for clarifying working environment practices (Cropanzano and Mitchell, 2005), social exchange theory can assist with clarifying why psychological contract breach influences worker results and their retaliation in form of counterproductive work behavior. The pitch of social exchange theory is that "social trade involves activities dependent upon the remunerating responses of others, which over the long run accommodate commonly and compensating exchanges and connections" (Cropanzano and Mitchell, 2005).

In an organization, a person may expect a reasonable and adjusted trade connection between the person in question and the organization. Besides, individuals will act as per the prizes they got (Cropanzano and Mitchell, 2005). In this way, the employee demonstrations whether the psychological contract has been satisfied. At the point when the representative's desires have not been acknowledged, psychological contract breach may happen (Robinson and Bennett, 1995). Therefore, the worker may distinguish a result of a lopsided trade connection between that person and the boss. So as to reestablish the equilibrium in the social exchange, the worker may decline to satisfy a portion of their commitments (Zhao et al., 2007). According to norm of reciprocity the subordinates then under such toxic leaders reciprocate in a social relation via counterproductive work behavior.

$\mathbf{H}_{3}$ : Psychological Contract Breach mediates the relationship between Toxic Leadership and Counterproductive Work Behavior.

\subsection{Moderating role of Proactive Personality}

Psychological breach of contract is treated as two way organization and employee relation that is disrupted either intentionally or unintentionally by the organization (Dulac et al., 2008, Zhao et al., 2007, Morrison and Robinson, 1997). And when employees experience psychological contract breach they consider lack of responsibility and concern for them at the part of organization (Johnson and O'Leary-Kelly, 2003, Zhao et al., 2007). In response to which employees may drop their work performance and concentration (Spindler, 1994).. The established relation is a socio-economic relation. And if the exchange of social relation is broken by organization, the employees may act similar to organization in a retaliation process. Similarly, Organizational Support Theory and Perceptual Control Theory both theories state that when employees experience breach of their psychological contract by the bad supervisor they are allotted, employees retaliate and reciprocate the same behavior towards organization in form of counterproductive work behavior. Aselage and Eisenberger (2003) state that if employees are provided with valued resources in two-way relation, they would less or not involve in deviant behaviors. But the case is said to be opposite if such resources are snatched from employees resulting in psychological contract breach.

The above-mentioned pattern is mostly of reactive personalities. The proactive personalities are opposite to reactive personalities and show a different pattern in regards to psychological contract breach. Subordinates who develop a psychological contract breach due to toxic or poisonous leader may either act proactively or reactively. Reactive subordinates may response to such negative behaviors developing psychological contract breach by counterproductive work behavior as a 
retaliation. However, proactive personalities holding a significant proportion of resources that help them tackle negative stressors at workplace unaccompanied by emotions being effected (Park and DeFrank, 2018). Previously few researchers have studied proactive personalities with counterproductive work behavior (Zhao et al., 2013, Zhang et al., 2019b). counterproductive work behavior is a retaliation process in which employee intends to harm or damage the organization in response to negativity and stress he/she receives in form of psychological contract breach (Spector et al., 2006). Psychological contract breach is an unexpected outcome for employees that reduces effort engagement (Agarwal and Bhargava, 2013) and comprises of rudeness (Bordia et al., 2008, Sayers et al., 2011) as illustrated by some previous studies. Proactive personalities have a practical appeal towards both their individual and corporate life (Bateman, 2017). They have a propensity to hold and deal with tough situations (Bateman, 2017) like psychological contract breach and so forth they are less likely to to adopt at counterproductive work behavior. Proactive have a capacity to develop skills to encounter and deal with stressors (Cunningham and De La Rosa, 2008) which reduces their chances to indulge in reactive mechanism like counterproductive work behavior to psychological contract breach. They also use methods that aid them taking upon and dealing with future problem and difficulties (Parker et al., 2006). In short proactive personalities have a greater tendency to deal and handle with stressors as psychological contract breach instead of reacting counterproductively. Such traits of proactive help them solve reactions like counterproductive work behavior in response to psychological contract breach.

$\mathbf{H}_{4}$ : Proactive Personality moderates the relationship between Psychological Contract Breach and Counterproductive Work Behavior.

Fig 2.1: Conceptual Framework

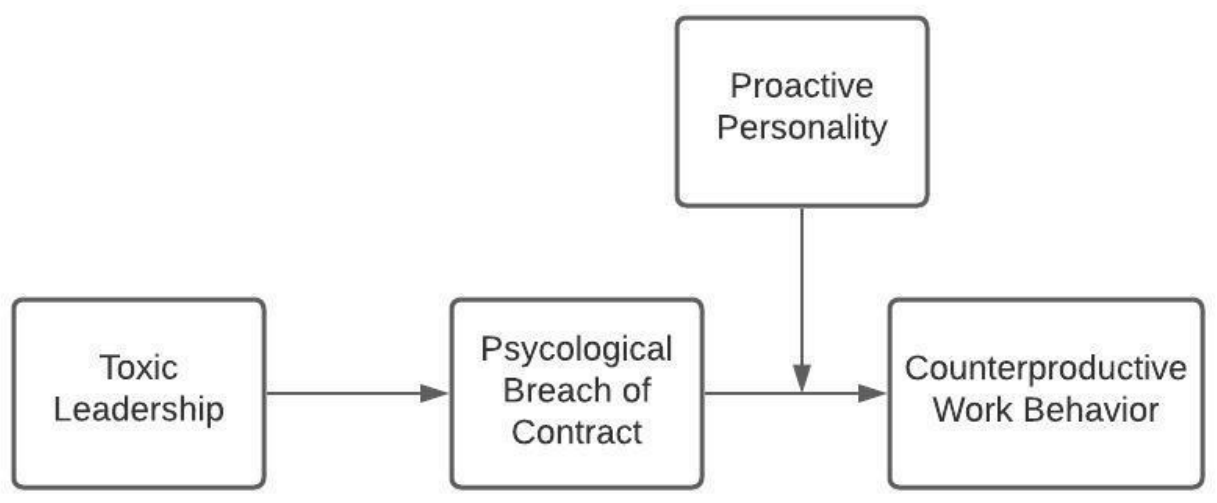

\section{Methodology}

\subsection{Sample and Procedure}

The applied model was tested in healthcare sector of Pakistan. The sample population were the nurses of public sector hospitals in major cities of Pakistan. A total of 355 sample size was selected. The sample was tested both descriptively and statistically. Sem-PLS software is used to assess the model. Sem-PLS is the finest software with regards to its user friendly interface and its exceptional analytical and graphical artistry (Davari and Rezazadeh, 2013). A quantitative study was conducted to test the hypothesis. According to Global Web Index quantitative study is fruitful for research purpose as provide in-depth and detail data, encouraging discussion and allows more flexibility. Different nurses from public sector hospitals were asked to fill the questionnaires. As nurses are the most neglected and badly treated professions in Pakistan (Chauhan, 2014). They were asked to rate their bosses in term of toxic leader and had to identify counterproductive reactions in response to it with psychological contract breach as mediator and proactive personalities as moderator. This is a single 
filed study. The response rate is $70 \%$ from the entire sample of 355 nurses. The data was collected cross-sectionally. A five-point Likert scale was established to test the hypothesis. The scale ranged from $1=$ Strongly Disagree to $5=$ Strongly Agree with Neutrality at its middle point 3 and was used to provide respondents a uniform and balanced way to answer the questionnaires (Joshi et al., 2015).

Demographics details of sample were also measured in terms of their gender, age, income status, qualification and experience. Most of the sample had age between 20-29 (47.9\%), income between Rs 41,000 - Rs 50,000 (35.8\%), education up to Bachelors (42.3\%) and experience between 1-5 years (33.8\%). Female nurses formed the majority of sample population.

\subsection{Measures}

All the constructs used in the study to measure variables are already established constructs in English language. The sample population of this research is bilingual and understands the questionnaire fully.

\subsubsection{Toxic Leadership}

The toxic leadership is assessed on 15-item scale established by Yavaş (2016) with reliability $\alpha=0.79$. The sample items are "My supervisor puts his own failures on our shoulders" and "My supervisor, as personnel, we have to behave according to his mood".

\subsubsection{Psychological Contract Breach}

The psychological contract breach is assessed on 5-item scale established by Robinson and Morrison (2008) with reliability $\alpha=0.92$. The sample items are "Almost all the promises made by my employer during recruitment have been kept so far" and "I have not received everything promised to me in exchange for my contributions".

\subsubsection{Counterproductive Work Behavior}

The counterproductive work behavior is assessed on 10-item scale established by Spector et al. (2010) with reliability $\alpha=0.78$. The sample items are "Purposely wasted your employer's materials/supplies" and "Came to work late without permission".

\subsubsection{Proactive Personality}

The proactive personality is assessed on 10-item scale established by Spector et al. (2010) with reliability $\alpha=0.86$. The sample items are "Wherever I have been, I have been a powerful force for constructive change" and "I love being a champion for my ideas, even against others' opposition".

\section{Results}

This study has utilized PLS-Sem software for the purpose of research analysis. This analysis technique is composed of two steps. First is the measurement model which is used to utilize to evaluate the validity and reliability of the factor loadings of the constructs. Second step is of the structural model. In it relationship of constructs is evaluated by coefficients, $p$-value and t-value.

In the measurement model Cronbach alpha and composite reliability factors are used to assess the reliability of the constructs. If the Cronbach alpha is greater than 0.70 and composite reliability is also above 0.70 then the construct is said to be reliable. Rho-A must be between Cronbach alpha and composite reliability for a reliable construct. Validity has two types convergent and discriminant. The convergent validity value is evaluated in regards to Average Variance Extracted (AVE) and Factor Loadings. For a construct to be valid must have AVE values $>0.50$ and Factor loading values $>0.70$. Discriminant validity declares a construct to be valid when square roots are higher than the correlation. 


\subsection{Summary of measurement model}

\begin{tabular}{ccccc}
\multicolumn{5}{c}{ Correlation Analysis } \\
\hline CWB & CWB & PCB & PP & TL \\
PCB & 1 & & & \\
PP & 0.926 & 1 & 1 & \\
TL & 0.419 & 0.41 & 0.497 & 1 \\
\hline
\end{tabular}

The table mentioned above is showing the results for correlation analysis. All variables are showing a positive correlation with each other. Some variables are showing strong, and some are showing weak correlations to each other.

\begin{tabular}{ccccc}
\hline & $\begin{array}{c}\text { Cronbach's } \\
\text { Alpha }\end{array}$ & rho_A & Composite Reliability & $\begin{array}{c}\text { Average Variance Extracted } \\
\text { (AVE) }\end{array}$ \\
\hline CWB & 0.853 & 0.858 & 0.901 & 0.696 \\
PCB & 0.811 & 0.819 & 0.889 & 0.728 \\
PP & 0.864 & 0.876 & 0.9 & 0.644 \\
TL & 0.881 & 0.892 & 0.905 & 0.577 \\
\hline
\end{tabular}

The above presented results are showing that the values of Composite reliability each variable are an acceptable level i.e., greater than 0.7 , so the data for each variable is reliable. Moreover, AVE Criterion also shows that each variable has convergent validity. Furthermore, the cross loading for each variable have been showing the discriminant validity. So, there is no issue for both convergent and discriminant validity in the data.

In first portion the results for measurement model are presented. In measurement model, the items for each variable have acceptable values. Toxic Leadership (TL) have been taken into account for the measurement of Toxic Leadership with values greater than 0.6 and P-value less than 0.05 . Five items for Aversive Leadership (AL) have been taken into account for measurement with values greater than 0.6 and $P$-value less than 0.05 . Despotic leadership (DL) is also measured by five items with values greater than 0.6 and are significant with P-Value less than 0.05. Psychological Breach of Contract (PCB), Counterproductive Behavior (CWB) and Proactive Personality (PP) have been measured by five items with value greater than 0.6 and $p$-value less than 0.05 .

\section{Discriminant Validity}

\begin{tabular}{ccccc}
\hline & CWB & PCB & PP & TL \\
\hline CWB & 0.834 & & & \\
PCB & 0.926 & 0.853 & & \\
PP & 0.419 & 0.41 & 0.802 & \\
TL & 0.783 & 0.729 & 0.497 & 0.759 \\
\hline
\end{tabular}

Further, the cross loadings of the tested constructs depict the discriminate validity mentioned in the above table. There is only one relation in the whole hypothesized model lacking discriminant validity. A shortage of discriminant validity in relation may be due to lapses in the items of the constructs (M R Ab Hamid et al; 2017).

\subsection{Structural Model (Testing of Hypothesis)}

The structural model relationships significancy is evaluated on basis of path coefficients $p$ value and $t$ value. If the $\beta>0.2, p$ value $<0.05$ and $t$ value $>1.96$ then the relationship is declared significant among the constructs. 


\begin{tabular}{ccc}
\hline & R Square & R Square Adjusted \\
\hline CWB & 0.883 & 0.882 \\
PCB & 0.532 & 0.531 \\
\hline
\end{tabular}

The above presented results are showing the values of R-square and Adjusted R-Square. R-square shows the explanatory power of the model. In our research model, Effect of Toxic Leadership (TL) on Psychological Breach of contract (PCB) and Counterproductive Behavior (CWB) has been captured. So, in case of Counterproductive Behavior (CWB), the explanatory power is $88.2=3 \%$ and in case of Psychological Breach of Contract (PCB) the explanatory power of the model is $53.2 \%$.

\subsubsection{Direct Effect of $T L$ on $P C B$ and $C W B$ and Direct effect of $P C B$ on $C W B$}

\begin{tabular}{cccccc}
\hline & $\begin{array}{c}\text { Original } \\
\text { Sample (O) }\end{array}$ & $\begin{array}{c}\text { Sample } \\
\text { Mean (M) }\end{array}$ & $\begin{array}{c}\text { Standard Deviation } \\
\text { (STDEV) }\end{array}$ & T Statistics & $\begin{array}{c}\text { P } \\
\text { Values }\end{array}$ \\
\hline $\begin{array}{c}\text { Moderating Effect } \\
\mathbf{1} \rightarrow \text { CWB }\end{array}$ & 0.019 & 0.02 & 0.015 & 1.24 & 0.216 \\
PCB $>$ CWB & 0.763 & 0.762 & 0.052 & 14.723 & 0 \\
PP $>$ CWB & -0.004 & -0.003 & 0.016 & 0.259 & 0.796 \\
TL $>$ CWB & 0.224 & 0.224 & 0.04 & 5.667 & 0 \\
TL $>$ PCB & 0.729 & 0.73 & 0.023 & 31.62 & 0 \\
\hline
\end{tabular}

4.2.2. Indirect Effect of $A L, D L, E L$ and $T L$ on $C W B$

\begin{tabular}{lccccc}
\hline & $\begin{array}{c}\text { Original } \\
\text { Sample } \\
(\mathbf{O})\end{array}$ & $\begin{array}{c}\text { Sample } \\
\text { Mean (M) }\end{array}$ & $\begin{array}{c}\text { Standard } \\
\text { Deviation } \\
\text { (STDEV) }\end{array}$ & T Statistics & $\begin{array}{c}\text { P } \\
\text { Values }\end{array}$ \\
\hline TL $>$ PCB $->$ CWB & 0.556 & 0.557 & 0.045 & 12.471 & 0 \\
\hline
\end{tabular}

$\mathbf{H}_{1}$ : Toxic Leadership has positive significant influence on Counterproductive Behavior.

The co-efficient of Toxic Leadership (TL) in direction towards counterproductive Behavior (CWB) is positive with $p$-value less than 0.05 , which means TL has positive significant influence on counterproductive Behavior. The co-efficient of Toxic Leadership, while Counterproductive Work Behavior is dependent variable, is 0.211 with $P$-value 0.000 ( $P$-value $<0.05$ ), which indicates that if one unit of Toxic Leadership is increased then Counterproductive Work Behavior will also increase by 0.211 units and vice versa. So, the results for this hypothesis are showing that Toxic leadership (TL) has positive and significant influence on counterproductive behavior (CWB) and $\mathrm{H} 1$ is accepted.

$\mathrm{H}_{2}$ : Psychological Breach of Contract has positive significant influence on Counterproductive Behavior.

The co-efficient of Psychological Breach of Contract (PCB) in direction towards counterproductive Behavior (CWB) is positive with p-value less than 0.05 , which means PCB has positive significant influence on counterproductive Behavior. The co-efficient of psychological contract breach, while counterproductive work behavior is dependent variable, is 0.508 with $P$-value 0.000 ( $P$-value $<0.05)$, which indicates that if one unit of psychological contract breach is increased then counterproductive 
work behavior will also increase by 0.508 units and vice versa. So, the results for this hypothesis are showing that Psychological Breach of Contract (PCB) has positive and significant influence on counterproductive behavior (CWB). So $\mathrm{H} 2$ is accepted on the basis of the statistical results.

$\mathbf{H}_{3}$ : Psychological Breach of Contract has mediating role in relationship of Toxic Leadership with counterproductive Behavior.

The direct influence of Toxic Leadership (TL) on Psychological Breach of Contract (PCB) is positive and significant and its influence on Counterproductive Behavior (CWB) is positive and significant. Furthermore, the direct effect of psychological Breach of contract (PCB) is also positive and significant. Thus, all the conditions for mediation of Psychological Breach of Contract (PCB) in relationship of Toxic Leadership (TL) with Counterproductive Behavior are fulfilled. Moreover, the indirect effect of Toxic Leadership (TL) towards counterproductive Behavior (CWB) through Psychological Breach of Contract $(P C B)$ is positive and significant with $p$-value less than 0.05 , which means psychological contract breach has mediation in relationship of Toxic Leadership with counterproductive work behavior. On the basis of the empirical results $\mathrm{H} 3$ is accepted.

$\mathbf{H}_{4}$ : Proactive Personality weakens the relationship of Psychological contract Breach with the counterproductive Behavior.

The co-efficient of Proactive Personality (PP) in direction towards counterproductive Behavior (CWB) is negative with $p$-value more than 0.05 , which means Proactive Personality (PP) has negative insignificant influence on counterproductive Behavior. The co-efficient of $\mathrm{PP}$, while counterproductive work behavior is dependent variable, is -0.004 with P-value 0.796 ( $P$-value $>0.05)$, which indicates that if one unit of PP is increased then counterproductive work behavior will not get effected. Moreover, the Proactive Personality is not playing moderating role in relationship of Psychological Breach of contract with Counterproductive Behavior as interaction term of Proactive Personality (PP) and Psychological Contract Breach (PP X PCB) (Moderating Effect) is showing insignificant influence with Pvalue $>0.05$ on Counterproductive Behavior. Moreover, the co-efficient of interaction term (Moderating effect) is negative i.e., 0.019 with $P$-value $>0.05$. These results are showing that proactive personality (PP) doesn't moderates the relationship of psychological breach of contract with counterproductive behavior.

\section{Discussion}

The main focus of this study was to numerically compute and evaluate the direct relationship among toxic leadership and their employees' counterproductive work behavior. It also investigated the indirect relationship through underlying constructs of employees' psychological contract breach. These relationships were inspected in the healthcare sector of Pakistan focusing on the nursing area because it is among the significant contributing sectors to the current scenario of Covid 19 in Pakistan (Masih and Gulzar, 2018)( Pakistan Economic Survey 2018-19, 2019). The data was gathered from hospital nurses working under some supervision to analyze the impact of their leaders' behavior on their work-oriented outputs. The empirical analysis indicated that the results obtained were in accordance with the hypothesized relationships.

This study has some surprising results. The results show that toxic leader despite of their poisonous characteristics have a significant but positive impact on counterproductive work behavior. Results showed a significant negative impact of toxic leadership upon psychological contract breach in partial mediation model but a positive impact of psychological contract breach on counterproductive work behavior has also been explored by several previous studies (Jamil et al., 2013, Botsford Morgan and King, 2012, Raja et al., 2004).

\subsection{Direct Effect}

Toxic leadership is usually associated with poisonous characteristics impacting subordinates (Lipman-Blumen, 2006). Due to their destructive and dysfunctional traits these leaders impose a continuous poisonous effect on subordinates, groups and organizations as well (Lipman-Blumen, 
2006). Such leaders create unnecessary hopelessness and negative values among the subordinates serving in a same organization. Singh et al. (2018) explored in his study that such leaders promote their darker side by letting down the confidence and interest of their subordinates dragging down their overall morale generating negative emotions. According to Singh et al. (2018) the subordinates of such leaders have a greater capability of indulging in counterproductive work behavior. A situation having negative emotions are created by toxic leaders is quite likely to involve subordinates into counterproductive work behavior (Spector et al., 2010). The quantitative results of the research showed a similar pattern where subordinates facing higher toxicity by leaders were found to be more involved in counterproductive work behavior.

Toxic Leadership when comes to psychological contract breach have a significant yet negative impact. The reason might be the different perceptions of toxicity at work. Singh et al. (2017) in their article articulated that employees perceive toxicity differently when belonging to different demographics. For instance, employees with higher education tends to perceive more toxicity from leaders than with less education (Singh et al., 2017). Festinger (1954) in this regard articulated that employees when facing a bad situation have a contrasting nature. They contrast themselves to their staff-mates to evaluate the intensity of negativity or loss at their end. Such situation created by toxic leadership; subordinates may not have breach of their psychological contract as they mark themselves for the better behaviors of their leaders as compared to their peers. As psychological contract breach is considered to be mutual commitment between the two parties (Zhou, 2014); another reason for negative association between the two variables is that the other party (subordinates) may not consider such behaviors as a factor of breach of psychological contract. The toxic leader functions with an exaggerated sense of self-confidence and from profound self-interest (DS Wilson - Forbes Online, 2014). Their interest might not always violate employees' psychological contract.

Psychological contract breach was found to have significant positive impact on counterproductive work behavior. The relation have been significantly established by many past researchers in different demographics (Ahmed et al., 2016, Ishaq and Shamsher, 2016, Jensen et al., 2010). Griep and Vantilborgh (2018) in their study postulated that psychological contract breach and counterproductive work behavior are associated positively in regards to social exchange theory. Any factor causing psychological contract breach generates a sense of low-esteem and negativity in employees which elicit a response in the form of counterproductive work behavior. According to Griep and Vantilborgh (2018) counterproductive work behavior is a retaliation process to psychological contract breach. As employees release their frustration and stress when they perceive psychological contract breach in form of counterproductive work behavior.

\subsection{Indirect Effect}

The mediation of psychological contract breach exists between toxic leadership and counterproductive work behavior as illustrated by the results. Psychological contract breach has a significant relationship with both Toxic Leadership and counterproductive work behavior. Here, the toxic leadership has a positive impact on psychological contract breach and psychological contract breach have a positive impact on counterproductive work behavior. This summarizes that subordinates might involve in counterproductive work behavior in response to a toxic leader and consider leader toxicity as a source of psychological contract breach. When employees assess and respond to their psychological contract, under a toxic leadership, they do not do so in a void. Rather, such assessments are made relative to a definite situation (Morrison and Robinson, 1997).

Lipmen-Blumen (2005) investigated certain characteristics of such toxic leaders that harm both the subordinates and the organization. Lipmen-Blumen (2005) found toxic leaders to be poisonous, adopt a deleterious practices and policies that includes unreachable targets, developing excessive competition and create a blame-game culture. As per Fraher (2016), toxic leaders set destructive targets and utilize destructive techniques of command. These traits of toxic leaders lead to greater negativity among followers with increased stressed as they have to work extra working hours to reach such goals and bear too much politics to sustain in excessive competition. This stress and exhaustion 
lead to breach of their psychological contracts. For which subordinates react or retaliate in form of counterproductive work behavior.

But psychological contract breach is a definite source of counterproductive behaviors at work (Ahmed et al., 2016, Ishaq and Shamsher, 2016, Jensen et al., 2010). Based on the social exchange theory, we know that employees with psychological contract breach may believe that they are unfavorably treated by their organization, which could elicit negative attitudes leading to damaging behaviors. Furthermore, when psychological contract breach comes into existence, employees may establish a belief that the organization lacks truthfulness (Johnson and O'Leary-Kelly, 2003, Zhao et al., 2007). Therefore, it develops a positive relationship between psychological contract breach and counterproductive work behavior (Li and Chen, 2018).

Finally, the proactive in organization are found to be not moderating the relationship between psychological contract breach and counterproductive work behavior as it is ineffective in the bond between the two variables. Few of the previous studies have highlighted before the connectiveness of proactive personality and counterproductive work behavior (Zhao et al., 2013, Zhang et al., 2019a). Another research supports the notion that psychological contract breach and employee proactiveness are negatively associated (Jafri, 2014). These previous researches a bit different to our results. A proactive personality have an ability to reduce stressors and handle such situation easily (Park and DeFrank, 2018) but these handling ability is only useful when proactive are provided with supportive environment. According to Belschak and Hartog (2010) proactive persons are not always useful in dealing with threatening or harsh situations as in order to be proactive they have to bare additional stress leading to mor breach and counterproductivity at work. Also, proactive workers may assess the benefits to cost ratio associated with a situation like psychological contract breach and might also behave counterproductively to save cost or effort required for it.

\section{Theoretical Implications}

In Pakistan, the idea of toxic leadership is a neglected area for research purpose. According to the information of previous studies, the current research study is exceptional that has discovered the experimental proof for the presence of toxic leadership in health sector of Pakistan and distinguished it as the forerunner of counterproductive work behavior in light of the fact that after thorough writing search no observational proof was found in this unique situation. Further, by contemplating the idea of counterproductive work behavior goal in health sector it made commitment to the current writing since it is one of the difficult issues looked by hospitals of Pakistan. Likewise, hidden ideas of workers' psychological contract and subordinate's proactivity is not having the intervening function on the relationship of toxic leadership with counterproductive work behavior which is not adequately researched particularly in Pakistani nursing sector. Hereafter, the current analysis added to the current writing may attempt to address the distinguished gaps in writing.

\section{Practical Implications}

Our results hold a few significant administrative implications. First of all, firms should put more accentuation on hindering leaders' toxic conduct thinking about its exorbitant results. Firms ought to illuminate managers with the antagonistic outcomes brought about by toxic oversight, and may join rules or approaches to rebuff toxic practices. Specifically, recognizing that casualties of misuse are bound to the psychological contract of subordinates by toxic leaders, it is pivotal for firms to set up certain sheltered channels for subordinates to report or voice out any toxic leadership conduct in the work environment.

Second, the hidden part of psychological contract further causes organizations to notice the significance of a solid labor force (Halbesleben, 2006, Tepper, 2007). Firms ought to offer extra help and asset-based intercessions to cradle mishandled workers' experience of passionate fatigue. For instance, firms could give mental meeting/consultation services to those casualties and tune in to their 
voice. Besides, businesses could execute worker wellbeing progress program to recognize the wellbeing status of their employees occasionally.

At long last, our outcomes with respect to the intensifying impacts of toxic leaders with regards to high Leader Member Exchange Theory underline the basic effect of management practices on subordinates' prosperity and retaliation conduct. Awful conduct in a by and large great relationship actually has unfavorable impact and even turns out to be more terrible progressively in form of counterproductive work behavior. Administrators ought not accept every so often abusing an "ingathering" subordinate or the individuals who trust and regard them as a non-serious deal. These subordinates really are more delicate to the negative treatment by bosses and therefore act more contrarily towards the organization. Undoubtedly, boss's ought to carry on emphatically and reliably in driving their subordinates. Firm preparing project ought to be led to alert bosses regarding the harmful outcomes of toxic conduct just as the significance of positive and predictable supervision practice in managing their subordinates.

\section{Limitations and Future Research}

There are surely some limitations in the research which can be thought about by future specialists. To begin with, the number of populations in this research was confined to the nursing sector of Pakistan. This puts a requirement to the generalizability to the entire service area of Pakistan and even in different areas. Future analysts can contemplate the other service-related organizations of Pakistan which incorporates hoteling organizations, educational institutes, security firms, and postal service firms and so on. A research concentrates between various service organizations or among health related and different areas in Pakistan can be directed.

Moreover, this research study considered public hospitals of Pakistan however a correlation between private and public was not thought of. Thusly, future specialists can likewise direct a correlation concentrate between these two sorts of hospitals to distinguish where toxic leadership and counterproductive work behavior among subordinates is all the more overarching. Additionally, future specialists can think about equivalent interest from the chosen hospitals which couldn't be made conceivable in this exploration concentrate because of cost and time limitations.

The consequences of demographics dissemination show that the majority of the members of the current research study were mostly females which is viewed as a constraint for exploration regarding equivalent consideration of male and female workers. Future scientists can speak to an equivalent investment of both and can likewise direct a correlation of conclusions with respect to their leaders. This research was cross sectional in nature. Future scientists can direct a longitudinal report to dissect the impact of toxic leaders on their subordinates because of which connections among variables can be better grasped.

This research has a quantitative exploration plan and during the cycle of information assortment the author confronted reluctance from members to round out the poll with respect to their leaders. Hence, future analysts can lead one on one meeting with members which may bring about better comprehension of the variables. Moreover, this research concentrates just centered around a couple of progresses that are affected by the toxic leaders. Future specialists can consider different advances which when connect with toxic leaders may make issues in the organizations, for example, work degenerate conduct, authoritative pessimism, and hierarchical citizenship conduct. Besides, notwithstanding understanding the results of toxic leaders, future analysts can concentrate in on distinguishing the method for dealing with stress to manage such leaders.

At long last, because of the limitations of time and costing issue the analyst was simply ready to gather information from hospitals in the major cities of Pakistan that bring about restricting the generalizability of this examination study. Subsequently, future researchers can gather the information from more urban areas of Pakistan. 


\section{Conclusion}

The conclusion drawn from this study is that nurses in Pakistan face toxic leadership and may involve in counterproductive work behaviors but are likely to have breach of their psychological contracts. The reasons could be excessive stress and exhaustion they bear at work. Employee proactiveness was found to play an insignificant role in reducing counterproductive work behaviors in response to psychological contract breach as they have to put an extra effort to deal with it which they might not find useful in comparison to the benefits associated. Toxic leadership due to its poisonous and self-serving characteristics generate stress and negative emotions in subordinates leading them to act counterproductively as retaliation process as explained by both Leader Member Exchange Theory and Social Exchange theory in the article.

\section{References}

1. Aasland, M. S., Skogstad, A., Notelaers, G., Nielsen, M. B. \& Einarsen, S. 2010. The prevalence of destructive leadership behaviour. British Journal of management, 21, 438-452.

2. Agarwal, U. A. \& Bhargava, S. 2013. Effects of psychological contract breach on organizational outcomes: Moderating role of tenure and educational levels. Vikalpa, 38, 13-26.

3. Ahmed, E., D’netto, B., Chelliah, J. \& Fein, E. 2016. Psychological contract breach: Consequences of unkept promises of permanent employment. Contemporary Management Research, 12.

4. Ali, K. 2014. The effects of leader-member exchange and employee wellbeing towards employee turnover intention. Deakin University.

5. Altheide, D., Adler, P., Adler, P., Altheide, D., Lippincott, J. \& America, U. S. O. 1978. Social Meanings Of Employee Theft (From Crime At The Top-Deviance In Business And The Professions, 1978 By John M Johnson And Jack D Douglas-See Ncj-47130).

6. Aquino, K., Lewis, M. U. \& Bradfield, M. 1999. Justice constructs, negative affectivity, and employee deviance: A proposed model and empirical test. Journal of Organizational Behavior, 20, 1073-1091.

7. Aryee, S., Chen, Z. X., Sun, L.-Y. \& Debrah, Y. A. 2007. Antecedents and outcomes of abusive supervision: test of a trickle-down model. Journal of applied psychology, 92, 191.

8. Aselage, J. \& Eisenberger, R. 2003. Perceived organizational support and psychological contracts: A theoretical integration. Journal of Organizational Behavior: The International Journal of Industrial, Occupational and Organizational Psychology and Behavior, 24, 491-509.

9. Ashford, S. J. \& Black, J. S. 1996. Proactivity during organizational entry: The role of desire for control. Journal of Applied psychology, 81, 199.

10.Ashforth, B. 1994. Petty tyranny in organizations. Human relations, 47, 755-778.

11.Bal, P. M., De Lange, A. H., Jansen, P. G. \& Van Der Velde, M. E. 2008. Psychological contract breach and job attitudes: A meta-analysis of age as a moderator. Journal of vocational behavior, $72,143-$ 158.

12.Bateman, T. S. 2017. Proactive goals and their pursuit. Proactivity at work: Making things happen in organizations, 295-329.

13.Bateman, T. S. \& Crant, J. M. 1993. The proactive component of organizational behavior: A measure and correlates. Journal of organizational behavior, 14, 103-118.

14.Bell, R. M. 2017. The dysfunction junction: The impact of toxic leadership on follower effectiveness. Regent University.

15.Bensman, J. \& Gerver, I. 1963. Crime and punishment in the factory: The function of deviancy in maintaining the social system. American Sociological Review, 588-598.

16.Bies, R. J., Tripp, T. M. \& Kramer, R. 1997. At the breaking point. Antisocial behavior in organizations, 18-36.

17.Bindl, U. K. \& Parker, S. K. 2010. 32 Feeling good and performing well? Psychological engagement and positive behaviors at work. Handbook of employee engagement: Perspectives, issues, research and practice, 385.

18.Blau, P. M. 1964. Social exchange theory. Retrieved September, 3, 62. 
19.Bordia, P., Restubog, S. L. D. \& Tang, R. L. 2008. When employees strike back: investigating mediating mechanisms between psychological contract breach and workplace deviance. Journal of Applied Psychology, 93, 1104.

20.Botsford Morgan, W. \& King, E. B. 2012. Mothers' psychological contracts: Does supervisor breach explain intention to leave the organization? Human Resource Management, 51, 629-649.

21.Burns Jr, W. A. 2017. A Descriptive Literature Review of Harmful Leadership Styles: Definitions, Commonalities, Measurements, Negative Impacts, and Ways to Improve These Harmful Leadership Styles. Creighton Journal of Interdisciplinary Leadership, 3, 33-52.

22.Buunk, A. P. \& Gibbons, F. X. 2007. Social comparison: The end of a theory and the emergence of a field. Organizational Behavior and Human Decision Processes, 102, 3-21.

23.Campbell, C. H., Ford, P., Rumsey, M. G., Pulakos, E. D., Borman, W. C., Felker, D. B., De Vera, M. V. \& Riegelhaupt, B. J. 1990. Development of multiple job performance measures in a representative sample of jobs. Personnel psychology, 43, 277-300.

24.Caniëls, M. C., Semeijn, J. H. \& Renders, I. H. 2018. Mind the mindset! The interaction of proactive personality, transformational leadership and growth mindset for engagement at work. Career Development International.

25.Cantisano, G. T., Domínguez, J. F. M. \& Depolo, M. 2008. Psychological contract breach and outcomes: Combining meta-analysis and structural equation models. Psicothema, 20, 487-496.

26.Carver, C. S. \& Scheier, M. F. 1982. Control theory: A useful conceptual framework for personalitysocial, clinical, and health psychology. Psychological bulletin, 92, 111.

27.Cassar, V. \& Briner, R. B. 2011. The relationship between psychological contract breach and organizational commitment: Exchange imbalance as a moderator of the mediating role of violation. Journal of Vocational Behavior, 78, 283-289.

28.Ceschi, A., Sartori, R., Dickert, S. \& Costantini, A. 2016. Grit or honesty-humility? New insights into the moderating role of personality between the health impairment process and counterproductive work behavior. Frontiers in psychology, 7, 1799.

29.Chauhan, N. 2014. Nursing in Pakistan: Handle with care. The Express Tribune, 7.

30.Chen, P. Y. \& Spector, P. E. 1991. Negative affectivity as the underlying cause of correlations between stressors and strains. Journal of applied psychology, 76, 398.

31.Colbert, A. E., Mount, M. K., Harter, J. K., Witt, L. A. \& Barrick, M. R. 2004. Interactive effects of personality and perceptions of the work situation on workplace deviance. Journal of applied psychology, 89, 599.

32. Conway, N. \& Briner, R. B. 2009. Fifty years of psychological contract research: What do we know and what are the main challenges. International review of industrial and organizational psychology, 24, 71-131.

33.Cook, K. S. \& Whitmeyer, J. M. 1992. Two approaches to social structure: Exchange theory and network analysis. Annual review of Sociology, 18, 109-127.

34.Crant, J. M. 2000. Proactive behavior in organizations. Journal of management, 26, 435-462.

35. Cressey, D. R. 1953. Other people's money; a study of the social psychology of embezzlement.

36.Cropanzano, R. \& Mitchell, M. S. 2005. Social exchange theory: An interdisciplinary review. Journal of management, 31, 874-900.

37.Cunningham, C. J. \& De La Rosa, G. M. 2008. The interactive effects of proactive personality and work-family interference on well-being. Journal of Occupational Health Psychology, 13, 271.

38.Davari, A. \& Rezazadeh, A. 2013. Structural equation modeling with PLS. Tehran: Jahad University, 215, 224.

39.Deery, S. J., Iverson, R. D. \& Walsh, J. T. 2006. Toward a better understanding of psychological contract breach: A study of customer service employees. Journal of applied psychology, 91, 166.

40.Dobbs, J. M. \& Do, J. J. 2019. The impact of perceived toxic leadership on cynicism in officer candidates. Armed Forces \& Society, 45, 3-26.

41.Dulac, T., Coyle-Shapiro, J. A., Henderson, D. J. \& Wayne, S. J. 2008. Not all responses to breach are the same: The interconnection of social exchange and psychological contract processes in organizations. Academy of Management Journal, 51, 1079-1098. 
42.Einarsen, S., Aasland, M. S. \& Skogstad, A. 2007. Destructive leadership behaviour: A definition and conceptual model. The Leadership Quarterly, 18, 207-216.

43.Elle, S. A. 2012. Breaking the toxic leadership paradigm in the US Army. ARMY WAR COLL CARLISLE BARRACKS PA.

44.Emerson, R. M. 1976. Social exchange theory. Annual review of sociology, 2, 335-362.

45.Festinger, L. 1954. A theory of social comparison processes. Human relations, 7, 117-140.

46.Fox, S. \& Spector, P. E. 1999. A model of work frustration-aggression. Journal of organizational behavior, 20, 915-931.

47.Fraher, A. L. 2016. A toxic triangle of destructive leadership at Bristol Royal Infirmary: A study of organizational Munchausen syndrome by proxy. Leadership, 12, 34-52.

48.Frese, M., Kring, W., Soose, A. \& Zempel, J. 1996. Personal initiative at work: Differences between East and West Germany. Academy of Management journal, 39, 37-63.

49.Frost, P. 2004. New challenges for leaders and their organization. Organization Dynamics, 33, 111127.

50.Fuller Jr, B. \& Marler, L. E. 2009. Change driven by nature: A meta-analytic review of the proactive personality literature. Journal of vocational behavior, 75, 329-345.

51.Gallus, J. A., Walsh, B. M., Van Driel, M., Gouge, M. C. \& Antolic, E. 2013. Intolerable cruelty: A multilevel examination of the impact of toxic leadership on US military units and service members. Military Psychology, 25, 588-601.

52.Ganster, D. C. \& Schaubroeck, J. 1991. Work stress and employee health. Journal of management, $17,235-271$.

53.Giacalone, R. A. \& Greenberg, J. 1997. Antisocial behavior in organizations, Sage.

54.Goldman, A. 2006. High toxicity leadership. Journal of Managerial Psychology.

55.Gouldner, A. W. 1954. Wildcat strike.

56.Greenberg, P. S., Greenberg, R. H. \& Antonucci, Y. L. 2007. Creating and sustaining trust in virtual teams. Business horizons, 50, 325-333.

57.Griep, Y. \& Vantilborgh, T. 2018. Let's get cynical about this! Recursive relationships between psychological contract breach and counterproductive work behaviour. Journal of Occupational and Organizational Psychology, 91, 421-429.

58.Griffin, R. W. \& Lopez, Y. P. 2005. "Bad behavior" in organizations: A review and typology for future research. Journal of Management, 31, 988-1005.

59. Halbesleben, J. R. 2006. Sources of social support and burnout: a meta-analytic test of the conservation of resources model. Journal of applied Psychology, 91, 1134.

60. Harper, D. 1990. Spotlight abuse-save profits. Industrial distribution, 79, 47-51.

61. Harvey, P., Stoner, J., Hochwarter, W. \& Kacmar, C. 2007. Coping with abusive supervision: The neutralizing effects of ingratiation and positive affect on negative employee outcomes. The Leadership Quarterly, 18, 264-280.

62. Ho, V. T. \& Levesque, L. L. 2005. With a little help from my friends (and substitutes): Social referents and influence in psychological contract fulfillment. Organization science, 16, 275-289.

63. Hogan, J. \& Hogan, R. 1989. How to measure employee reliability. Journal of Applied psychology, $74,273$.

64. Hollinger, R. C. 1986. Acts against the workplace: Social bonding and employee deviance. Deviant Behavior, 7, 53-75.

65. Homans, G. C. 1974. Social behavior: Its elementary forms.

66.Burnhorning, D. N. 1970. The Other Worker: A Comparative Study of Industrial Relations in the United States and Japan. JSTOR.

67.Ishaq, H. M. \& Shamsher, Q. 2016. Effect of breach of psychological contracts on workplace deviant behaviors with the moderating role of revenge attitude and self-control. Pakistan Journal of Commerce and Social Sciences (PJCSS), 10, 69-83.

68.Jafri, H. 2014. Influence of personality on perception of psychological contract breach.

69.Jamil, A., Raja, U. \& Darr, W. 2013. Psychological contract types as moderator in the breachviolation and violation-burnout relationships. The Journal of psychology, 147, 491-515. 
70.Jensen, J. M., Opland, R. A. \& Ryan, A. M. 2010. Psychological contracts and counterproductive work behaviors: Employee responses to transactional and relational breach. Journal of Business and Psychology, 25, 555-568.

71.Jiang, H., Chen, Y., Sun, P. \& Yang, J. 2017. The relationship between authoritarian leadership and employees' deviant workplace behaviors: The mediating effects of psychological contract violation and organizational cynicism. Frontiers in Psychology, 8, 732.

72.Johnson, J. L. \& O'leary-Kelly, A. M. 2003. The effects of psychological contract breach and organizational cynicism: Not all social exchange violations are created equal. Journal of Organizational Behavior: The International Journal of Industrial, Occupational and Organizational Psychology and Behavior, 24, 627-647.

73.Joshi, A., Kale, S., Chandel, S. \& Pal, D. K. 2015. Likert scale: Explored and explained. Current Journal of Applied Science and Technology, 396-403.

74.Judge, T. A., Piccolo, R. F. \& Kosalka, T. 2009. The bright and dark sides of leader traits: A review and theoretical extension of the leader trait paradigm. The leadership quarterly, 20, 855-875.

75.Kickul, J. \& Lester, S. W. 2001. Broken promises: Equity sensitivity as a moderator between psychological contract breach and employee attitudes and behavior. Journal of business and psychology, 16, 191-217.

76.Kotter, J. P. 1973. The psychological contract: Managing the joining-up process. California management review, 15, 91-99.

77.Kurtulmuş, B. E. 2020. Toxic Leadership and Workplace Bullying: The Role of Followers and Possible Coping Strategies. The Palgrave Handbook of Workplace Well-Being, 1-20.

78.Leymann, H. \& Gustafsson, A. 1996. Mobbing at work and the development of post-traumatic stress disorders. European Journal of work and organizational psychology, 5, 251-275.

79.Li, S. \& Chen, Y. 2018. The relationship between psychological contract breach and employees' counterproductive work behaviors: the mediating effect of organizational cynicism and work alienation. Frontiers in Psychology, 9, 1273.

80.Lipman-Blumen, J. 2006. The allure of toxic leaders: Why we follow destructive bosses and corrupt politicians--and how we can survive them, Oxford University Press, USA.

81.Lipman-Blumen, J. 2010. Toxic leadership: a conceptual framework. Handbook of top management teams. Springer.

82.Lipmen-Blumen, J. 2005. The allure of toxic leaders. Oxford: Oxford University Press.

83.Luthans, F., Peterson, S. J. \& Ibrayeva, E. 1998. The potential for the "dark side" of leadership in post communist countries. Journal of World Business, 33, 185-201.

84.Mars, G. 1973. Chance, punters, and the fiddle: Institutionalized pilferage in a hotel dining room. The sociology of the workplace, 200-210.

85.Masih, S. \& Gulzar, L. 2018. Association of nurses' self perception about their public image and their job satisfaction in tertiary care hospitals, Karachi, Pakistan.

86. Mitchell, M. S. \& Ambrose, M. L. 2007. Abusive supervision and workplace deviance and the moderating effects of negative reciprocity beliefs. Journal of Applied Psychology, 92, 1159.

87.Morrison, E. W. \& Phelps, C. C. 1999. Taking charge at work: Extrarole efforts to initiate workplace change. Academy of management Journal, 42, 403-419.

88.Morrison, E. W. \& Robinson, S. L. 1997. When employees feel betrayed: A model of how psychological contract violation develops. Academy of management Review, 22, 226-256.

89.Naeem, F. \& Khurram, S. 2020. Influence of toxic leadership on turnover intention: The mediating role of psychological wellbeing and employee engagement. Pakistan Journal of Commerce and Social Sciences (PJCSS), 14, 682-713.

90.Naseer, S., Raja, U., Syed, F., Donia, M. B. \& Darr, W. 2016. Perils of being close to a bad leader in a bad environment: Exploring the combined effects of despotic leadership, leader member exchange, and perceived organizational politics on behaviors. The Leadership Quarterly, 27, 14-33.

91.Neuman, J. H. \& Baron, R. A. 1998. Workplace violence and workplace aggression: Evidence concerning specific forms, potential causes, and preferred targets. Journal of management, 24, 391419. 
92.Newman, A., Schwarz, G., Cooper, B. \& Sendjaya, S. 2017. How servant leadership influences organizational citizenship behavior: The roles of LMX, empowerment, and proactive personality. Journal of Business Ethics, 145, 49-62.

93.Nguyen, Q., Kuntz, J. R., Näswall, K. \& Malinen, S. 2016. Employee resilience and leadership styles: The moderating role of proactive personality and optimism. New Zealand Journal of Psychology (Online), 45, 13.

94.O'donohue, W., Hutchings, K. \& Hansen, S. D. 2018. Psychological contracts: enhancing understanding of the expatriation experience. Taylor \& Francis.

95.Oatley, K. \& Jenkins, J. M. 1992. Human emotions: Function and dysfunction. Annual review of psychology, 43, 55-85.

96.Ones, D. S., Viswesvaran, C. \& Schmidt, F. L. 1993. Comprehensive meta-analysis of integrity test validities: Findings and implications for personnel selection and theories of job performance. Journal of applied psychology, 78, 679.

97.Padilla, A., Hogan, R. \& Kaiser, R. B. 2007. The toxic triangle: Destructive leaders, susceptible followers, and conducive environments. The Leadership Quarterly, 18, 176-194.

98.Park, J. H. \& Defrank, R. S. 2018. The role of proactive personality in the stressor-strain model. International Journal of Stress Management, 25, 44.

99.Parker, C. 2000. Performance measurement. Work study.

100. Parker, S. K., Wall, T. D. \& Jackson, P. R. 1997. "That's not my job": Developing flexible employee work orientations. Academy of management journal, 40, 899-929.

101. Parker, S. K., Williams, H. M. \& Turner, N. 2006. Modeling the antecedents of proactive behavior at work. Journal of applied psychology, 91, 636.

102. Paulhus, D. L. 2014. Toward a taxonomy of dark personalities. Current Directions in Psychological Science, 23, 421-426.

103. Paulhus, D. L. \& Williams, K. M. 2002. The dark triad of personality: Narcissism, Machiavellianism, and psychopathy. Journal of research in personality, 36, 556-563.

104. Pelletier, K. L. 2010. Leader toxicity: An empirical investigation of toxic behavior and rhetoric. Leadership, 6, 373-389.

105. Penney, L. M. \& Spector, P. E. 2005. Job stress, incivility, and counterproductive work behavior (CWB): The moderating role of negative affectivity. Journal of Organizational Behavior: The International Journal of Industrial, Occupational and Organizational Psychology and Behavior, 26, 777-796.

106. Quratulain, S., Khan, A. K., Crawshaw, J. R., Arain, G. A. \& Hameed, I. 2018. A study of employee affective organizational commitment and retention in Pakistan: The roles of psychological contract breach and norms of reciprocity. The International Journal of Human Resource Management, 29, 2552-2579.

107. Raja, U., Johns, G. \& Ntalianis, F. 2004. The impact of personality on psychological contracts. Academy of management Journal, 47, 350-367.

108. Rank, J., Carsten, J. M., Unger, J. M. \& Spector, P. E. 2007. Proactive customer service performance: Relationships with individual, task, and leadership variables. Human Performance, 20, 363-390.

109. Reed, G. E. 2004. Toxic leadership. Military review, 84, 67-71.

110. Reed, G. E. \& Bullis, R. C. 2009. The impact of destructive leadership on senior military officers and civilian employees. Armed Forces \& Society, 36, 5-18.

111. Reed, G. E. \& Olsen, R. A. 2010. Toxic leadership: Part deux. ARMY COMBINED ARMS CENTER FORT LEAVENWORTH KS MILITARY REVIEW.

112. Robin, G. D. 1969. Employees as offenders. Journal of Research in Crime and Delinquency, 6, 17-33.

113. Robinson, S. L. \& Bennett, R. J. 1995. A typology of deviant workplace behaviors: A multidimensional scaling study. Academy of management journal, 38, 555-572. 
114. Robinson, S. L. \& Greenberg, J. 1998. Employees behaving badly: Dimensions, determinants and dilemmas in the study of workplace deviance. Journal of Organizational Behavior (1986-1998), 1.

115. Robinson, S. L. \& Rousseau, D. M. 1994. Violating the psychological contract: Not the exception but the norm. Journal of organizational behavior, 15, 245-259.

116. Rosenthal, S. A. \& Pittinsky, T. L. 2006. Narcissistic leadership. The leadership quarterly, 17, 617-633.

117. Rousseau, D. 1995. Psychological contracts in organizations: Understanding written and unwritten agreements, Sage publications.

118. Rousseau, D. M. 1989. Psychological and implied contracts in organizations. Employee responsibilities and rights journal, 2, 121-139.

119. Rousseau, D. M. 2011. The individual-organization relationship: The psychological contract.

120. Rousseau, D. M. \& Tijoriwala, S. A. 1998. Assessing psychological contracts: Issues, alternatives and measures. Journal of Organizational Behavior: The International Journal of Industrial, Occupational and Organizational Psychology and Behavior, 19, 679-695.

121. Sackett, P. \& Devore, C. 2001. Counterproductive behaviour at work. Handbook of industrial work and organizational psychology. Personal Psychology 1, 145-164. London, UK, Sage Publications.

122. Sayers, J. K., Sears, K. L., Kelly, K. M. \& Harbke, C. R. 2011. When employees engage in workplace incivility: The interactive effect of psychological contract violation and organizational justice. Employee Responsibilities and Rights Journal, 23, 269-283.

123. Schmid, E. A., Pircher Verdorfer, A. \& Peus, C. 2019. Shedding light on leaders' self-interest: theory and measurement of exploitative leadership. Journal of Management, 45, 1401-1433.

124. Schmidt, A. A. 2008. Development and validation of the toxic leadership scale.

125. Schmidt, G. B. 2016. How adult attachment styles relate to perceived psychological contract breach and affective organizational commitment. Employee Responsibilities and Rights Journal, 28, 147-170.

126. Schyns, B. \& Hansbrough, T. 2010. When leadership goes wrong: Destructive leadership, mistakes, and ethical failures, IAP.

127. Singh, N., Dev, S. \& Sengupta, S. 2017. Perceived toxicity in leaders: Through the demographic lens of subordinates. Procedia computer science, 122, 114-121.

128. Singh, N., Sengupta, S. \& Dev, S. 2018. Toxic leadership: The most menacing form of leadership. Dark Sides of Organizational Behavior and Leadership. IntechOpen.

129. Skarlicki, D. P. \& Folger, R. 1997. Retaliation in the workplace: The roles of distributive, procedural, and interactional justice. Journal of applied Psychology, 82, 434.

130. Skarlicki, D. P., Folger, R. \& Tesluk, P. 1999. Personality as a moderator in the relationship between fairness and retaliation. Academy of management journal, 42, 100-108.

131. Spector, P. E., Bauer, J. A. \& Fox, S. 2010. Measurement artifacts in the assessment of counterproductive work behavior and organizational citizenship behavior: Do we know what we think we know? Journal of Applied Psychology, 95, 781.

132. Spector, P. E., Fox, S., Penney, L. M., Bruursema, K., Goh, A. \& Kessler, S. 2006. The dimensionality of counterproductivity: Are all counterproductive behaviors created equal? Journal of vocational behavior, 68, 446-460.

133. Spector, P. E. \& O'connell, B. J. 1994. The contribution of personality traits, negative affectivity, locus of control and Type $A$ to the subsequent reports of job stressors and job strains. Journal of Occupational and Organizational psychology, 67, 1-12.

134. Spielberger, C., Sydeman, S. \& Maruish, M. 1994. State-trait anxiety inventory and state-trait anger expression inventory. The use of psychological testing for treatment planning and outcome assessment. Lawrence Erlbaum Associates, Hillsdale, New Jersey.

135. Spindler, G. S. 1994. Psychological contracts in the workplace-a lawyer's view. Human Resource Management, 33, 325-333. 
136. Steele, J. P. 2011. Antecedents and consequences of toxic leadership in the US Army: A two year review and recommended solutions. CENTER FOR ARMY LEADERSHIP FORT LEAVENWORTH KS.

137. Sturges, J., Conway, N., Guest, D. \& Liefooghe, A. 2005. Managing the career deal: The psychological contract as a framework for understanding career management, organizational commitment and work behavior. Journal of Organizational Behavior: The International Journal of Industrial, Occupational and Organizational Psychology and Behavior, 26, 821-838.

138. Taylor, L. \& Walton, P. 1971. Industrial Sabotage'in Stan Cohen (ed.); Images of Deviance. Penguin.

139. Tepper, B. J. 2000. Consequences of abusive supervision. Academy of management journal, 43, 178-190.

140. Tepper, B. J. 2007. Abusive supervision in work organizations: Review, synthesis, and research agenda. Journal of management, 33, 261-289.

141. Tepper, B. J., Duffy, M. K., Henle, C. A. \& Lambert, L. S. 2006. Procedural injustice, victim precipitation, and abusive supervision. Personnel Psychology, 59, 101-123.

142. Tepper, B. J., Duffy, M. K., Hoobler, J. \& Ensley, M. D. 2004. Moderators of the relationships between coworkers' organizational citizenship behavior and fellow employees' attitudes. Journal of Applied Psychology, 89, 455.

143. Tian, Q., Zhang, L. \& Zou, W. 2014. Job insecurity and counterproductive behavior of casino dealers-the mediating role of affective commitment and moderating role of supervisor support. International Journal of Hospitality Management, 40, 29-36.

144. Topa, G., Morales, J. F. \& Moriano, J.-A. 2009. Psychological contract breach and social identity: Their influences on Spanish soldiers' job satisfaction and organizational citizenship behaviour. Estudios de Psicología, 30, 303-315.

145. Tornau, K. \& Frese, M. 2013. Construct clean-up in proactivity research: A meta-analysis on the nomological net of work-related proactivity concepts and their incremental validities. Applied Psychology, 62, 44-96.

146. Tripp, T. M., Bies, R. J. \& Aquino, K. 2002. Poetic justice or petty jealousy? The aesthetics of revenge. Organizational behavior and human decision processes, 89, 966-984.

147. Turnley, W. H. \& Feldman, D. C. 2000. Re-examining the effects of psychological contract violations: unmet expectations and job dissatisfaction as mediators. Journal of organizational behavior, 21, 25-42.

148. Van Dyne, L. \& Lepine, J. A. 1998. Helping and voice extra-role behaviors: Evidence of construct and predictive validity. Academy of Management journal, 41, 108-119.

149. Wang, Y.-D. \& Hsieh, H.-H. 2014. Employees' reactions to psychological contract breach: A moderated mediation analysis. Journal of Vocational Behavior, 85, 57-66.

150. Webster, V., Brough, P. \& Daly, K. 2016. Fight, flight or freeze: Common responses for follower coping with toxic leadership. Stress and Health, 32, 346-354.

151. Wilson-Starks, K. Y. 2003. Toxic leadership. Transleadership, Inc, 1, 2016.

152. Wu, T.-Y. \& Hu, C. 2009. Abusive supervision and employee emotional exhaustion: Dispositional antecedents and boundaries. Group \& Organization Management, 34, 143-169.

153. Yavaş, A. 2016. Sectoral differences in the perception of toxic leadership. Procedia-Social and Behavioral Sciences, 229, 267-276.

154. Zapf, D., Knorz, C. \& Kulla, M. 1996. On the relationship between mobbing factors, and job content, social work environment, and health outcomes. European Journal of work and organizational psychology, 5, 215-237.

155. Zellars, K. L., Tepper, B. J. \& Duffy, M. K. 2002. Abusive supervision and subordinates' organizational citizenship behavior. Journal of applied psychology, 87, 1068.

156. Zhang, Y., Crant, J. M. \& Weng, Q. 2019a. Role stressors and counterproductive work behavior: The role of negative affect and proactive personality. International Journal of Selection and Assessment, 27, 267-279. 
157. Zhang, Y., Liu, X., Xu, S., Yang, L.-Q. \& Bednall, T. C. 2019b. Why abusive supervision impacts employee OCB and CWB: A meta-analytic review of competing mediating mechanisms. Journal of Management, 45, 2474-2497.

158. Zhao, H., Peng, Z. \& Sheard, G. 2013. Workplace ostracism and hospitality employees' counterproductive work behaviors: The joint moderating effects of proactive personality and political skill. International Journal of Hospitality Management, 33, 219-227.

159. Zhao, H., Wayne, S. J., Glibkowski, B. C. \& Bravo, J. 2007. The impact of psychological contract breach on work-related outcomes: a meta-analysis. Personnel psychology, 60, 647-680.

160. Zhou, J. 2014. Psychological contract, organizational commitment and work satisfaction: survey of researchers in Chinese state-owned engineering research institutions. Open Journal of Social Sciences, 2, 217. 